University for Business and Technology in Kosovo

UBT Knowledge Center

Oct 28th, 4:00 PM - 5:30 PM

\title{
The effect of a professor's attitude on University students' learning motivation. Case study: English Department
}

\author{
Mirsad Suhodolli \\ International Business College, mirsad.suhodolli@gmail.com
}

Follow this and additional works at: https://knowledgecenter.ubt-uni.net/conference

Part of the Education Commons

\section{Recommended Citation}

Suhodolli, Mirsad, "The effect of a professor's attitude on University students' learning motivation. Case study: English Department" (2017). UBT International Conference. 113.

https://knowledgecenter.ubt-uni.net/conference/2017/all-events/113

This Event is brought to you for free and open access by the Publication and Journals at UBT Knowledge Center. It has been accepted for inclusion in UBT International Conference by an authorized administrator of UBT Knowledge Center. For more information, please contact knowledge.center@ubt-uni.net. 


\title{
The Effect of a Professor's Attitude on University Students' Learning Motivation Case study: English Department- International Business College, Mitrovica- Kosovo
}

\author{
Mirsad Suhodolli ${ }^{1}$ \\ South East European University Tetovo, Macedonia \\ ms22394@seeu.edu.mk
}

\begin{abstract}
Dealing with students from different backgrounds is a very difficult job for university professors. This is seen in many instances when teaching them. The article in question gives a deeper insight into a very sensitive and a very detailed aspect of teaching: the effect of a professor's attitude on students' learning motivation. It is based, though, on the experience of the professors who use only English in the classroom. Special emphasis was given to the students from the Department of English which is a part of the International Business College located in Mitrovica (a town North of Kosovo). Despite being one of the main and the most sensitive issues in teaching, the article manages to tackle it in a very careful manner. It finds a balance between other elements of teaching on one hand and a professor's attitude on the other.
\end{abstract}

Keywords: Motivation, attitude, professor, role, relation.

\section{Introduction}

\section{Background of the study}

Dealing with students is not an easy job. It often requires much more than it is thought. It is due to this reason that many teachers find it difficult to manage the classroom in the most effective way possible. This is not all as not everything is just about managing the classroom but also about conveying the message of the lessons (lectures) to the students by also motivating them. This further means that a teacher is to really have the necessary attitude to help his/her students in these goals. This can be done by motivating them. It will further help them achieve higher levels of communication, therefore, "The primary goal of teachers of English as a second language (ESL) or English as a foreign language (EFL) is to develop desired levels of English language communication skills among their nonnative English speaking students"(Bernardo \& Gaerlan, 2001, p.1-2).

This, however, can be achieved in different ways. First, a teacher is to carefully observe his/her students on what ways they understand better and what attitude makes it easier to them to cope with in-class tasks. Second, the extent to which our students achieve something be it inside the classroom our outside it depends largely on how much we can motivate them. Making this possible is a big challenge for each and every teacher/ professor. Sometimes, this requires a long period of time; sometimes it can be achieved faster. One may ask, how can this be done the easiest? The answer lies on our experience with students. It is us teachers who know the students best. It is us who know more about each individual on how he/she acquires easier. Finally, having the necessary attitude towards our students proves how professional we, as teachers, are. This is given higher importance when we take into account the fact that, in most of the cases, it is the teacher himself/ herself that make students like the subject, in our case English. 
This depends largely on what kind of motivation we give our students. Giving them a good reason to learn is the best one and to do this we need to be aware of everything that gives our students a good will to achieve something. In other words, they should be given a strong feeling of achieving their future lifelong goals which is one of the best ways to involve them in whatever we want to teach. However, there are still obstacles in teaching students due to many reasons. One of the reasons is that some students, if not all, may have come to faculty after having had a long break from the secondary school. Some others, despite having continued with the studies upon completion of the secondary school, still feel they are not ready for such a challenge without a professor's support. Another reason is that university professors sometimes take things for granted, that is to say, they do not give students due consideration thinking that they are mature enough, which might be totally wrong. Thus, this is the strongest means of convincing in this study (research work): finding a balance between engaging students as much as needed without making them feel embarrassed and/or overburdened in any way and the proper attitude towards them. Another issue worth putting emphasis on based on this study is that the techniques the university level professors use in their daily work with students are to be changed as the need arises.

Besides, taking examples of our daily work explains it best. One such a good example is when a student told a professor that he hated English. Later on, the very same student became one of the best students in the class. What made it possible is the professor's good attitude which resulted in that student being motivated and consequently very successful. This further means that taking the slightest examples is not to be left aside. Rather, it should be boosted as much as possible. At this point, a professor is to pay attention to everything that happens in the classroom be it the students' mood as this might show that something is going well or it is wrong with the lectures being taught.

To what extent a professor's attitude influences students' learning motivation is the issue that this study was focused on and tackled. This study was conducted in the International Business College in Mitrovica- Kosovo respectively in the English Department. There are many reasons for this study having been conducted but it is worth stressing out only a few of them. First, this topic has not been dealt with sufficiently and secondly, as newly formed state, Kosovo's education system is not yet stable which implies that a lot more is to be done for all the education-related issues be solved and the topic in question is one of them.

Apart from this, students should be given the right guidelines, in other words, they should be taught on working on their own, not necessarily with the presence of professors. The question then rises: Do the students in our country (Kosovo) just learn or they also study? In many instances, students just learn, they actually do not study. They come to the classroom (lecture hall or whatever name we give it), listen to their professor, go back home and read the lectures so that they get a good grade. They do not really dig deeper into the lessons taught and being read. In some other cases, they just get the power point slides, print them out and allegedly get ready for the exams to come. There are many factors that cause this but motivation is one of them therefore having the right attitude in motivating them to study (not just learn) is way better than just making them check or circle certain answers on an answer sheet.

\section{Significance and purpose of the study}

Today, there are many universities, especially private ones. Taking this into account, the number of students completing studies in different fields has increased rapidly so has the number of professors. Therefore, taking this into account, a professor's attitude becomes crucial in the students future endeavors and success. 


\section{Research aims}

This research aims to highlight the effect that the attitude of professors has on students' learning motivation and their future success. It also aims to find the best methods/techniques to avoid any possible obstacles that may appear during learning/teaching process in the classroom. This can be seen further in this study.

\section{The objectives of this study}

One of the main objectives of this study is to bring forward the issue of a professors' attitude towards students and its importance in their motivation to learn and achieve more. This will further enable students and university professors not only take this issue more seriously but also work harder towards achieving this goal. Besides, by achieving this, they will pave the way for the future generations to come.

\section{Literature Review}

\section{The relation between talent and students' two types of motivation}

A lot has been written herein about professors' attitude and its relation with students' motivation which results in their success in their studies. There are many researchers who have also argued that professors' attitude is of vital importance in the success that students prove during their studies. Some others have also argued that talent is another important factor which helps this relation work accordingly. Therefore, "God-gifted talents, best teachers and best schooling augment the academic performance and students' motivation is prerequisite for students' accomplishment." (Afsal, H. et.al. 2010, p.80, book 1). This explains to some extent how important a teacher's attitude is.

There are two types of motivations that are mentioned by different researchers: intrinsic motivation and extrinsic motivation. There is a difference in students with these motivation types,

Thus students with intrinsic motivation are more enthusiastic, self driven, challenging and feel pleasure in their studies and students with extrinsic motivation try to drag themselves with academic assignments, feel compelled to learn, and always put minimal efforts to achieve maximum appreciations. Intrinsically motivated, students tend to utilize strategies that require more effort and that allow them to process information more intensely.

Condry and Chambers (1978) found that when students were confronted with multifarious intellectual tasks, those with an intrinsic direction used more logical information-gathering and decision-making strategies than did students who were extrinsically motivated (Afsal, H. et.al. 2010, p.81).

Based on this, a student is to set goals to himself/herself. This then is related to what type of motivation a student is led by. The question rises if a professor can play a role in this selection of either of the types of motivation. The answer to this question might seem easy but as this study was being carried out, it turned out to be rather a very difficult one.

At the very beginning of the academic year, there were students who were not motivated at all but after having attended classes of English and after the professor had a very positive attitude towards them have they become motivated. This was proven in that they were much more active 
during lectures and different exercises which included all four language skills. Yet, this is not all as working as a professor means having to work with students from different backgrounds. It is us professors who should teach our students not only our subject matter but also let them acquire new skills and help them manage these skills on their own, therefore,

In school, teachers manage much of students' learning. However, learning is enhanced if students can manage it themselves; moreover, once they leave school, people have to manage most of their own learning. To do this, they need to be able to establish goals, to persevere, to monitor their learning progress, to adjust their learning strategies as necessary and to overcome difficulties in learning. Students who leave school with the autonomy to set their own learning goals and with a sense that they can reach those goals are better equipped to learn throughout their lives. (Learning for Tomorrow's World - First Results from PISA, p.110, 2003)

The above cited lines show that, with the right attitude and help of professor (teacher) students can achieve a higher level of learning independence which is one of the main goals we should all aspire. It is exactly this area the study in question proved to be vitally important when dealing with students and this has to do with the skills our students acquire throughout their life, thus, "The acquisition of new skills over a life span is a remarkable human ability." (Li and Hernandez, 2007, p.638).

This is not beyond logic due to the fact that the span of concentration of the adult learner differs from that of the young learner but this does not necessarily mean that there are advantages for adult learners compared to young learners. Moreover, young learners don't necessarily have the feeling of shyness as the adult ones as is the case with some non-native speaker adults who go back to school after a long time and feel they can't express themselves. This all should be taken into consideration when dealing with pupils especially when it comes to reading comprehension skills. Thus, "Teachers will be relying on speaking and listening skills with younger children whereas L2 literacy is likely to be incorporated into teaching materials for the older age groups. (Pinter 2011)" (as cited in Burns \& Richards, 2012, p.107). Additionally, "Younger children are less able and less interested in comparing their L1 and the target language, whereas older children can rely on their L1 knowledge and skills" (Burns \& Richards, 2012, p.107-108).

\section{The way professors should talk to students}

There are some differences in dealing with university students. There are also similarities. What is same about it is that both: university professors and primary school teachers should emphasize with their students, therefore, "The way teachers talk to students-the manner in which they interact with them is one of crucial skills, but it does not demand technical expertise. It does, however, require teachers to skills. It does, however, require teachers to empathise with the people they are talking to" (Harmer, J., 2001, p.3).

\section{Research Methodology}

This chapter presents the methods used when conducting this study. It shows the best and the easiest possible ways in achieving the desired outcomes. This all was done in a very careful way for it all would clarify to the reader the mainstream of the study in question. Therefore, both: 
qualitative and quantitative methods were used. The research consisted of questionnaires, observations and interviews. There was not a strict order on which one would come first and which one would follow. It all went smoothly. Of course, everything was planned ahead and all the changes were thought of in advance.

\section{Research questions}

1. Does a professor's attitude have an effect on students' learning motivation?

2. Is the motivation a professor gives students determinant on how much students will achieve in their studies?

3. Does a professor's attitude help students engage more in the lectures taught?

\section{Research hypothesis}

- Professors' attitude has a great effect on students' learning motivation

- The motivation professors give students in most of the cases determine how much will students study and achieve their future goals

- Motivating students by having a due attitude makes it possible for the students engage in the lectures being taught

\section{Participants}

A hundred and fifty (150) both: male and female students from the first to the third year of study were involved in this study. The English teachers were involved in the study, too. Not only did the teachers and students participate in this study but the parents were also in a way involved be it indirectly.

\section{Research procedures}

This study was carried out in the International Business College in Mitrovica using quantitative and qualitative methods. The study was conducted through observations, questionnaires and interviews. It is for this reason that a one-month observation was carried out. First of all, both: the students and the professors were interviewed and on later phases were given questionnaires to fill in. Not only did the teachers welcome the research but they also claimed not to have had the opportunity to hear about such a study having been carried out which they considered to be of a vital importance and beneficial to the faculty in particular and educational system in general, so did the students.

\section{Conclusion}

As it has been seen from above, the effect that a professor's attitude has on students' learning motivation is highly important. It starts with individuals and ends up in groups. This means that 
a professor is to pay attention to every single student: his/her mood and everything that may influence his/her ability to learn and acquire in the classroom be it a problem he/she may have had outside the classroom. Through the study in question, it was seen that the attitude of professors is to be changed depending on how students acquire and learn best and this makes it a very sensitive issue in the new trend of teaching methodology. In other words, it should be adaptable. That is why; the study in question is ongoing due to its importance despite having been worked on for a long time.

\section{References:}

1. Afsal, H. ( 2010), A Study of University Students' Motivation and Its Relationship with Their Academic Performance. Independent Researcher Hong Kong, 1903Un Shing House, Un Chau Estate Cheung Shan Van Kownloon, Hong Kong. Retrieved on 13.10.2017 from http://www.ccsenet.org/journal/index.php/ijbm/article/view/5691/4612

2. Burns A. \& Richard J.C (2012), Pedagogy and Practice in English Language Teaching. Cambridge University Press, 32 Avenue of the Americas, New York, NY 100013-2473, USA.

3. Harmer, J. (2001). How to teach English. Edinburgh Gate, Harlow, Essex, CM20 2JE. England and Associated Companies throughout the World. ISBN 0582297966 Retrieved on 12.10.2017 from: http://elibrary.bsu.az/books_250/N_97.pdf

4. Knoll L, C. (2000): The relationship between motivation and reading comprehension. Grand Valley State University. Retrieved on 20.08.2015 from: http://scholarworks.gvsu.edu/cgi/viewcontent.cgi?article=1525\&context=theses

5. Li, P. \& Hernandez, E.A (2007). Age of Acquisition: Its Neural and Computational Mechanisms. University of Houston and University of Richmond. Retrieved on 08.01.2016 from: http://blclab.org/wp-content/uploads/2013/02/aoa07.pdf

6. OECD. Learning for Tomorrow's World First results from PISA (2004) -. Student Learning: Attitudes, Engagement and Strategies. Retrieved on 08.10.2017 from: http://studylib.net/doc/18818346/student-learning--attitudes--engagement-andstrategies

7. Taboada A. et al (n.d.) Effects of Motivational and Cognitive Variables on Reading Comprehension. College of Education \& Human Development George Mason University. Retrieved on 04.08.2015 from: http://cori.umd.edu/researchpublications/2008_toboada_tonks_etal.pdf 